\title{
Preferences of Agricultural Undergraduates of PAU, Ludhiana and PJTSAU, Hyderabad towards Agriculture as a Profession
}

\author{
Boda Mahesh Naik*, Rupinder Kaur and Lopamudra Mohapatra
}

Department of Extension Education, Punjab Agricultural University, Ludhiana - 141 004, Punjab, India

*Corresponding author

\begin{tabular}{|l|}
\hline Ke y w o r d s \\
Agriculture, \\
Preference, \\
Profession, \\
Undergraduate \\
\hline Article Info \\
\hline $\begin{array}{l}\text { Accepted: } \\
15 \text { July } 2019 \\
\text { Available Online: } \\
\text { 10 August } 2019\end{array}$ \\
\hline
\end{tabular}

A B S T R A C T
The present study was designed to identify the preferences of agricultural undergraduates towards agriculture as a profession. A sample of 120 students of final year B.Sc. Agriculture was drawn by following random sampling method from PAU, Ludhiana and PJTSAU, Hyderabad. Data were collected by distributing questionnaire to the respondents. Findings of the study reveal that 56.67 per cent of the respondents were in the age group of 23-25 years. About 52 per cent have scored more than 70 per cent in their latest academic performance, 53.33 per cent were from rural family background and 87.50 per cent respondents belonged to family size of 3-5 family members. It was found that 46.6 per cent of the respondent families had service as main occupation. Majority $(78.33 \%)$ of the respondents expressed their preferences to continue higher studies. The preference for research was ranked first by the respondents after M.Sc. whereas female respondents were interested in teaching and research field and male respondents were interested in research and extension after M.Sc. The service in the Department of Agriculture was ranked first by respondents followed by Assistant professor at University/College, Agro-based Industries, Banking sector and Department of Horticulture. In case of adopting agriculture for selfemployment, vegetable production was most preferred followed by farming and agri clinics and agri business centre.

\section{Introduction}

India is primarily concerned with agriculture and majority of the people depend upon agriculture for livelihood. Agricultural sector generates around 15 per cent of the national income, and 54 per cent of India's population is directly or indirectly included under agriculture. Agriculture plays major role in the development and sustainability of human civilisation (Frick et al., 1995). Thus development and modernization of agriculture sector helps in increasing the speed of economic development of the nation. In this context, apart from administration and research, agricultural education plays a crucial role in enhancing agricultural production in specific and development of rural society in broad. Due to these reasons, development of agriculture can be observed as a purpose of quality and quantity of trained manpower required for implementation of several agricultural development activities. The main purpose of agricultural education is to provide 
opportunities to the individuals so that they can utilize training for their self-employment and also to support in planning, implementation and evaluation of development programmes. In our country, higher agricultural education should be concerned with the education of both men and women for execution of different gender roles for adopting technical farming and in affecting agricultural policies. It can be said that the value of higher agricultural education implements a profound effect on all phases of agricultural development. The focus is not only on the needed practical training but is also on some well-planned activities like purpose to develop appropriate attitude, learning by doing, needed competences and sufficient confidence in students. In view the above facts present study entitled "Preferences of agricultural undergraduates of PAU, Ludhiana and PJTSAU, Hyderabad towards agriculture as a profession" was conducted in two state agricultural universities with the following objective: To study the Preferences of undergraduate agricultural students towards agriculture as a profession in PAU and PJTSAU.

\section{Materials and Methods}

\section{Location of the study}

The study was conducted in two state agricultural universities, i.e. College of Agriculture, Punjab Agricultural University (PAU), Ludhiana, Punjab and College of Agriculture, Professor Jayashankar Telangana State Agricultural University (PJTSAU), Hyderabad, Telangana.

\section{Selection of respondents}

Two universities (PAU, Ludhiana, Punjab and PJTSAU, Hyderabad, Telangana) were selected purposively for the study. A sample of 120 students from final year B.Sc. Agri.
(Hons) 6 year programme and B.Sc. (Agri.) 4 year programme were selected randomly from the two State Agricultural Universities (SAUs). The list of students was obtained from Dean, College of Agriculture of both the SAUs. From the sample of 120 students, 60 students were selected from Punjab Agricultural University (PAU), Ludhiana where 30 students were from B.Sc. Agri. (Hons) 6 year programme and 30 students from B.Sc. (Agri.) 4 year programme. Whereas B.Sc. Agri. (Hons) 6 year programme is not available in PJTSAU, so a sample of 60 students of B.Sc. (Agri.) was selected from the university. Thus, making a total sample size of 120 respondents.

\section{Results and Discussion}

\section{Preferences for continuing higher studies}

Preference was operationally defined as a greater liking for one alternative over others. It was considered to study the preferences for continuing higher studies in agriculture profession before ascertaining the preferences of the respondents for opting agriculture as a profession on completion of their study.

The information so collected is placed in table 1 , it was interesting to observe that a majority of the respondents $(78.33 \%)$ wanted to pursue higher studies after completing their graduation and only one fifth of the respondents did not want to pursue higher studies.

While comparing the sub-samples, in PAU, Ludhiana about 73 per cent respondents wanted to pursue higher studies and slightly more than one-fourth respondents did not want to pursue higher studies. Whereas in PJTSAU, Hyderabad; it was found that 83 per cent of respondents wanted to pursue higher studies and 17 per cent did not want to pursue higher studies. The reasons for not pursuing higher 
studies by few students were they wanted to prepare for government jobs as they wanted to settle early in life. The findings of the present study are in complete agreement with Sandhu (1975), Chawla (1989) and Mittal (2005) who reported in their investigation that majority of the respondents preferred to continue their higher studies.

\section{Rank wise preference for opting teaching, extension and research}

Preference was measured by giving ranks against each of the profession. It was considered to study the ranks gave by the students for teaching, research and extension after their post-graduation.

Data in table 2 reveal that preferences for research in agriculture obtained the first rank with overall score of 236 and teaching obtained the second rank with overall score of 188, whereas extension work in agriculture obtained the third rank with overall score of 157. In case of PAU, Ludhiana first rank was obtained by research with score of 108 , it may be due to the reason that more research facilities are present in the campus.

Extension work obtained third rank with score of 79 as it is considered as difficult task and it requires more communication skills and time. Whereas in PJTSAU, Hyderabad research obtained first rank with score of 128 and extension work secured third rank with score of 78. Similar findings were reported by Punia and Singh (1981).

From the above findings it was noticed that respondents from both the universities preferred to join research field, it might be due to their interest towards research as more research facilities are present in the campus.

While extension was least preferred as it requires more indulgence in field work.
Distribution of respondents on the basis of gender regarding their preferences for nature of professional work after postgraduation

Data in table 3 reveal that female students in the PAU, Ludhiana mostly preferred teaching profession with overall score of 54 followed by research with score of 50 whereas extension was least preferred with score of 14 . While male students preferred extension profession with score of 65 followed by research with score of 58 and teaching with score of 41 . Whereas in case of PJTSAU, Hyderabad more female students showed their preference towards research with score of 68, followed by teaching with score of 54 and extension with score of 20. While male students showed their preference towards research as their first preference with score of 60 and it was followed by extension with score 58 and teaching profession with score 39. While comparing both the universities, female students showed their least preference towards extension profession and high preference towards teaching and research. While male students showed their high preference towards research and extension and least preference towards teaching. The findings were in agreement with Sandhu (1975). From the above findings it was noticed that most of the female respondents were interested in the teaching field and least interested in extension field as they found it difficult to work in field. While male respondents shown interest in research and extension fields because they were more interested in filed activities.

\section{Preference for joining various organizations/institutions while opting agriculture as a profession}

In this table preference for various service sectors and self-employment sector has been analysed and interpreted in both the 
universities. It was measured on three point continuum i.e. not preferred, preferred and most preferred. Three score was given for most preferred, two and one score given for preferred and not preferred respectively. Data in table 4 reveal that in the service sector, State department of agriculture, Assistant professor in university/college and Agro-based industries obtained first, second and third ranks respectively. Whereas in selfemployment sector, Vegetable production, Crop production and Agri. Clinic and Agri. Business Centre obtained first, second and third ranks respectively. While comparing preferences of PAU, Ludhiana and PJTSAU, Hyderabad students, there was significant difference in the State Department of
Horticulture, Banking sector and Bee keeping. The difference in State Department of Horticulture might be due to better employment opportunities in Punjab than in Telangana. The preference for banking sector is more in PAU, Ludhiana as students in this campus are more interested to work in this sector as compared to PJTSAU, Hyderabad. The difference in Bee keeping might be due to better facilities for establishment of apiculture units in Punjab as compared to Telangana, so students in PAU are preferring bee keeping more as compared to students in PJTSAU. The findings of service sector are in agreement with Grewal (2005) and Mittal (2005) and in contradiction with Narwal and Dixit (1992) and Rashid et al., (2002).

Table.1 Distribution of respondents according to preferences for higher studies

\begin{tabular}{|c|c|c|c|}
\hline \multirow{2}{*}{ Preference } & PAU, Ludhiana. $\left(\mathbf{n}_{\mathbf{1}}=\mathbf{6 0}\right)$ & $\begin{array}{c}\text { PJTSAU, Hyderabad } \\
\left(\mathbf{n}_{\mathbf{2}}=\mathbf{6 0}\right)\end{array}$ & $\begin{array}{c}\text { Total respondents. } \\
(\mathbf{n = 1 2 0})\end{array}$ \\
\cline { 2 - 4 } & $\mathbf{f}(\mathbf{\%})$ & $\mathbf{f})$ & $\mathbf{f}(\mathbf{\%})$ \\
\hline Yes & $44(73.33)$ & $50(83.00)$ & $94(78.33)$ \\
\hline No & $16(26.67)$ & $10(17.00)$ & $26(21.67)$ \\
\hline
\end{tabular}

Table.2 Distribution of respondents according to preferences for nature of professional work after post-graduation

\begin{tabular}{|c|l|c|c|c|c|c|c|}
\hline S. No. & Preferences & \multicolumn{2}{|c|}{$\begin{array}{c}\text { PAU, Ludhiana } \\
\left(\mathbf{n}_{\mathbf{1}}=\mathbf{6 0}\right)\end{array}$} & \multicolumn{2}{|c|}{$\begin{array}{c}\text { PJTSAU, Hyderabad } \\
\left(\mathbf{n}_{\mathbf{2}}=\mathbf{6 0}\right)\end{array}$} & \multicolumn{2}{|c|}{$\begin{array}{c}\text { Total respondents } \\
(\mathbf{n = 1 2 0})\end{array}$} \\
\cline { 3 - 8 } & & Score & Rank & Score & Rank & Total score & Rank \\
\hline 1. & Research & 108 & I & 128 & I & 236 & I \\
\hline 2. & Teaching & 95 & II & 93 & II & 188 & II \\
\hline 3. & Extension & 79 & III & 78 & III & 157 & III \\
\hline
\end{tabular}

Table.3 Distribution of respondents on the basis of gender according to preferences for nature of professional work after post-graduation

\begin{tabular}{|c|c|c|c|c|c|c|c|c|c|}
\hline \multirow{2}{*}{ S. No. } & \multirow{2}{*}{ Preferences } & \multicolumn{3}{|c|}{ PAU, Ludhiana $\left(\mathbf{n}_{\mathbf{1}}=\mathbf{6 0}\right)$} & \multicolumn{3}{c|}{ PJTSAU, Hyderabad $\left(\mathbf{n}_{\mathbf{2}}=\mathbf{6 0}\right)$} \\
\cline { 3 - 10 } & & \multicolumn{2}{|c|}{ Male } & \multicolumn{2}{c|}{ Female } & \multicolumn{2}{c|}{ Male } & \multicolumn{2}{c|}{ Female } \\
\cline { 3 - 10 } & & Score & Rank & Score & Rank & Score & Rank & Score & Rank \\
\hline $\mathbf{1}$ & Research & 58 & II & 50 & II & 60 & I & 68 & I \\
\hline $\mathbf{2}$ & Teaching & 41 & III & 54 & I & 39 & III & 54 & II \\
\hline 3 & Extension & 65 & I & 14 & III & 58 & II & 20 & III \\
\hline
\end{tabular}


Table.4 Distribution of respondents according to preferences for joining various organizations/institutions while opting agriculture as a profession

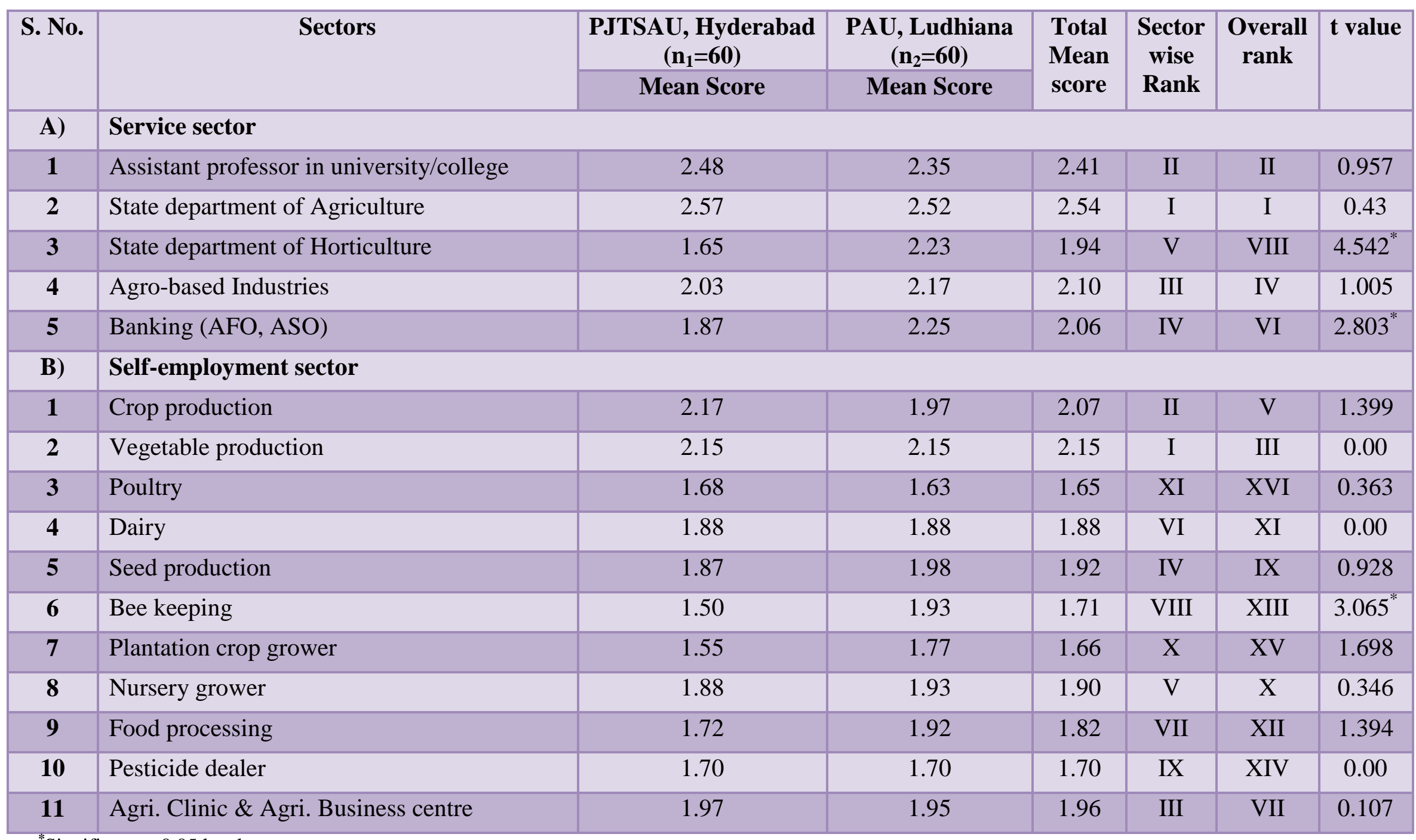

*Significant at 0.05 level 
Table.5 Distribution of respondents on the basis of gender according to preferences for joining various organizations/institutions while opting agriculture as a profession

\begin{tabular}{|c|c|c|c|c|c|c|c|c|c|}
\hline \multirow{3}{*}{$\begin{array}{l}\text { S. No } \\
\text { A) }\end{array}$} & \multirow{3}{*}{$\begin{array}{l}\text { Sectors } \\
\text { Service sector }\end{array}$} & \multicolumn{4}{|c|}{ PJTSAU, Hyderabad $\left(n_{1}=60\right)$} & \multicolumn{4}{|c|}{ PAU, Ludhiana $\left(n_{2}=60\right)$} \\
\hline & & \multicolumn{2}{|l|}{ Male } & \multicolumn{2}{|c|}{ Female } & \multicolumn{2}{|l|}{ Male } & \multicolumn{2}{|c|}{ Female } \\
\hline & & Mean Score & Rank & Mean Score & Rank & Mean Score & Rank & Mean Score & Rank \\
\hline 1 & Assistant professor at university/college & 2.05 & II & 2.38 & I & 2.13 & V & 2.32 & I \\
\hline 2 & State department of agriculture & 2.50 & I & 2.11 & II & 2.46 & I & 2.14 & III \\
\hline 3 & State department of horticulture & 1.42 & $\mathrm{~V}$ & 1.36 & IV & 2.21 & II & 2.19 & II \\
\hline 4 & Agro-based industries & 2.01 & III & 1.23 & $\mathrm{~V}$ & 2.15 & IV & 1.31 & $\mathrm{~V}$ \\
\hline 5 & Banking & 1.59 & IV & 1.84 & III & 2.16 & III & 2.11 & IV \\
\hline B) & Self-employment sector & & & & & & & & \\
\hline 1 & Crop production & 2.35 & II & 1.21 & IV & 2.03 & II & 1.26 & VIII \\
\hline 2 & Vegetable production & 2.41 & I & 2.10 & I & 2.26 & I & 2.07 & I \\
\hline 3 & Poultry & 1.76 & IX & 1.01 & VIII & 1.69 & XI & 1.10 & IX \\
\hline 4 & Dairy & 1.98 & IV & 1.12 & VI & 1.86 & VIII & 1.05 & $\mathrm{X}$ \\
\hline 5 & Seed production & 1.88 & VII & 1.06 & VII & 1.90 & VI & 1.32 & VII \\
\hline 6 & Bee keeping & 1.23 & $\mathrm{XI}$ & 0.95 & IX & 2.01 & III & 1.85 & III \\
\hline 7 & Plantation crop grower & 1.36 & $\mathrm{X}$ & 0.88 & $\mathrm{X}$ & 1.72 & $\mathrm{X}$ & 1.52 & V \\
\hline 8 & Nursery grower & 1.99 & III & 1.20 & V & 1.90 & $\mathrm{~V}$ & 1.56 & IV \\
\hline 9 & Food processing & 1.96 & $\mathrm{~V}$ & 1.23 & III & 1.84 & IX & 1.46 & VI \\
\hline 10 & Pesticide dealer & 1.95 & VI & 0.85 & XI & 1.89 & VII & 0.96 & $\mathrm{XI}$ \\
\hline 11 & Agri. Clinic \& Agri. Business centre & 1.85 & VIII & 2.01 & II & 1.91 & IV & 1.98 & II \\
\hline
\end{tabular}


Table.6 Distribution of respondents according to the reasons for preferring agriculture as an occupation

\begin{tabular}{|c|c|c|c|c|c|}
\hline S. No & Reasons & $\begin{array}{c}\text { PAU, } \\
\text { Ludhiana } \\
\left(\mathbf{n}_{\mathbf{1}}=60\right) \\
\mathbf{f}(\%)\end{array}$ & $\begin{array}{c}\text { PJTSAU, } \\
\text { Hyderabad } \\
\left(\mathbf{n}_{2}=60\right) \\
\mathbf{f}(\%)\end{array}$ & $\mathrm{Z}$ value & $\begin{array}{c}\text { Total } \\
\text { respondents } \\
(\mathbf{n}=120)\end{array}$ \\
\hline 1. & Easy work & $\begin{array}{c}8 \\
(13.33)\end{array}$ & $\begin{array}{c}2 \\
(3.33)\end{array}$ & $1.98^{*}$ & $\begin{array}{c}10 \\
(8.33)\end{array}$ \\
\hline 2. & $\begin{array}{l}\text { Suitable for my family } \\
\text { conditions }\end{array}$ & $\begin{array}{c}37 \\
(61.67)\end{array}$ & $\begin{array}{c}33 \\
(55.00)\end{array}$ & 0.74 & $\begin{array}{c}70 \\
(58.33)\end{array}$ \\
\hline 3. & Having large land holding & $\begin{array}{c}26 \\
(43.33)\end{array}$ & $\begin{array}{c}22 \\
(36.67)\end{array}$ & 0.74 & $\begin{array}{c}48 \\
(40.00)\end{array}$ \\
\hline 4. & Commercially profitable & $\begin{array}{c}31 \\
(51.67)\end{array}$ & $\begin{array}{c}27 \\
(45.00)\end{array}$ & 0.73 & $\begin{array}{c}58 \\
(48.33)\end{array}$ \\
\hline 5. & Not require much labour & $\begin{array}{c}5 \\
(8.33)\end{array}$ & $\begin{array}{c}1 \\
(1.67)\end{array}$ & 1.67 & $\begin{array}{c}6 \\
(5.00)\end{array}$ \\
\hline 6. & Less investment & $\begin{array}{c}26 \\
(43.33)\end{array}$ & $\begin{array}{c}8 \\
(13.33)\end{array}$ & $3.64^{*}$ & $\begin{array}{c}34 \\
(28.33)\end{array}$ \\
\hline 7. & $\begin{array}{l}\text { Raise the social status of } \\
\text { the family }\end{array}$ & $\begin{array}{c}35 \\
(58.33)\end{array}$ & $\begin{array}{c}24 \\
(40.00)\end{array}$ & $2.00^{*}$ & $\begin{array}{c}59 \\
(49.16)\end{array}$ \\
\hline
\end{tabular}

"Significant at 0.05 level

Table.7 Distribution of respondents according to future preferences after completing B.Sc. (Agri.) degree

\begin{tabular}{|c|c|c|c|c|c|c|c|c|}
\hline \multirow[t]{2}{*}{ S. No } & \multirow[t]{2}{*}{ Preference } & \multicolumn{2}{|c|}{$\begin{array}{l}\text { PAU, Ludhiana } \\
\qquad\left(\mathbf{n}_{1}=60\right)\end{array}$} & \multicolumn{2}{|c|}{$\begin{array}{c}\text { PJTSAU, } \\
\text { Hyderabad } \\
\left(\mathbf{n}_{2}=60\right)\end{array}$} & \multirow[b]{2}{*}{$Z$ test } & \multicolumn{2}{|c|}{$\begin{array}{c}\text { Overall } \\
\text { respondents } \\
(\mathbf{n}=120)\end{array}$} \\
\hline & & $f^{*}(\%)$ & Rank & $f^{*}(\%)$ & Rank & & $f *(\%)$ & Rank \\
\hline 1. & $\begin{array}{l}\text { Going abroad for } \\
\text { higher studies }\end{array}$ & $\begin{array}{c}30 \\
(50.00)\end{array}$ & III & $\begin{array}{c}15 \\
(25.00)\end{array}$ & III & $2.82 * *$ & $\begin{array}{c}45 \\
(37.50)\end{array}$ & III \\
\hline 2. & $\begin{array}{l}\text { To become an } \\
\text { entrepreneur }\end{array}$ & $8(13.33)$ & IV & $\begin{array}{c}6 \\
(10.00)\end{array}$ & V & 0.56 & $\begin{array}{c}14 \\
(11.66)\end{array}$ & IV \\
\hline 3. & $\begin{array}{l}\text { To prepare for a } \\
\text { government job }\end{array}$ & $\begin{array}{c}36 \\
(60.00)\end{array}$ & II & $\begin{array}{c}38 \\
(63.33)\end{array}$ & II & 0.37 & $\begin{array}{c}74 \\
(61.67)\end{array}$ & II \\
\hline 4. & $\begin{array}{l}\text { To pursue higher } \\
\text { study in India }\end{array}$ & $\begin{array}{c}44 \\
(73.33)\end{array}$ & I & $\begin{array}{c}50 \\
(83.33)\end{array}$ & I & 1.32 & $\begin{array}{c}94 \\
(78.33)\end{array}$ & I \\
\hline 5. & To go for private job & $\begin{array}{c}2 \\
(3.33)\end{array}$ & V & $\begin{array}{c}8 \\
(13.33)\end{array}$ & IV & $1.98^{* *}$ & $\begin{array}{c}10 \\
(8.33)\end{array}$ & V \\
\hline
\end{tabular}

Significant at 0.05 level 
Distribution of respondents on the basis of gender regarding their preferences for joining various organizations/institutions while opting agriculture as a profession

Data in table 5 reveal that in the service sector of PJTSAU, Hyderabad, female students wanted to join as Assistant professor in university /college and second preference was given to state department of agriculture. It was followed by banking, State Department of Horticulture and Agro-based industries. Whereas male students wanted to join in State Department of Agriculture followed by Assistant professor in university/college, Agro-based industries, Banking, and State department of horticulture. In PAU, Ludhiana female students also wanted to join as Assistant professor in university/college followed by State Department of Horticulture, State Department of Agriculture, Banking and Agro-based industries. In the selfemployment sector of PJTSAU, Hyderabad, the first preferences given by the female students were Vegetable production, Agri. Clinics and Agri. Business centres and Food processing, whereas least preference was given to Pesticide dealer. The first three preferences of the male students were Vegetable production, Crop production and Nursery grower, whereas least preference was given to Bee keeping. In case of PAU, Ludhiana the first three preferences of the female students were Vegetable production, Agri. Clinic and Agri. Business centre and Bee keeping, whereas least preference was given to Pesticide dealer. The first three reasons given by the male students were Vegetable production, Crop production and Bee-keeping. Whereas least preference was given to Poultry.

From data, it is clearly noted that female students from both the universities wanted to join as assistant professor in university/college because they were not willing to work in the field, whereas male students wanted to join in state department of agriculture as they preferred more to work in the field.

Reasons determining preferences of the respondents towards agriculture farming as an occupation

In table 6 various reasons for preferring agriculture as an occupation by the respondents from both the universities have been studied and interpreted. It was measured on two point continuum i.e. agree and disagree. One score was given for agree and zero score was given to disagree. Data in table 6 reveal that among the reasons for preferring agriculture as an occupation, the main three reasons given by the respondents determining their preference towards agriculture occupation were 'suitability to their family conditions' (58.33\%), 'raises the social status of the family' (49.16\%) and 'commercially profitable' (48.33\%). Other responses were 'possession of large land holding', 'less investment', 'easiness in working and 'less laborious' which were reported by 40 per cent, 28.33 per cent, 8.33 per cent and five per cent respectively. While comparing PAU, Ludhiana and PJTSAU, Hyderabad the three reasons reported by respondents were significantly different, the first one is 'easiness in working', the students of PAU preferred more because of having more advanced machinery in Punjab as compare to Telangana. The second reason was 'less investment', it was also preferred more by PAU students due to the availability of more subsidy, sufficient irrigation facilities and modern machinery with less use of labour. The third reason was 'raises the social status' of the family, PAU graduates felt agriculture raises the social status of the family due to the availability of large land holding. The findings were in agreement with Mittal (2005). 
From the above findings it was noticed that most of the respondents felt 'agriculture was commercially profitable', it raises the social status of the family and is suitable to family conditions but in contradiction they felt it required more labour and was difficult in working.

\section{Rank wise future preference after completing B.Sc. (Agri.) degree}

As indicated in table 7, future preference of the students after completing B.Sc. (Agri.) degree have been collected and interpreted in the rank wise manner. It is clear from data that majority of the respondents $(78.33 \%)$ preferred to pursue higher study in India after B.Sc. (Agri.) degree followed by preparing for government job preferred by about 61 . About 38 per cent of the students preferred going abroad for higher studies, 11.66 per cent preferred to become an entrepreneur and only 8.33 per cent preferred to go for private job. While comparing PAU, Ludhiana and PJTSAU, Hyderabad, there was significant difference between the preferences of students of PAU and PJTSAU. PAU students least preferred going for a private job and PJTSAU students not showed great preference for going abroad for higher studies after completion of B.Sc. (Agri) degree. The findings were in agreement with Grewal (2005).

It can be inferred from the above discussion that the preferences for research was ranked first it was followed by teaching and extension by the respondents after M.Sc. in both the universities. While comparing gender wise in PAU most of the female respondents wanted to join in teaching profession whereas male students wanted to join in extension jobs after M.Sc. In PJTSAU most of the male and female respondents wanted to join in research field. The preferential status for serving in the Department of Agriculture was ranked first in the service sector by the respondents followed by Assistant Professor in university or college, Agro-based industries, State Department of Horticulture and Banking respectively. The preferential status for agriculture as an occupation in the selfemployment sector, vegetable production was most preferred by the respondents and was ranked first, it was followed by farming and Agri. Clinics and Agri. Business centre. While comparing gender wise in both the universities male students wanted to join in state department of agriculture whereas female students wanted to join in education department. The most common reasons for opting agriculture as an occupation were, respondents felt agriculture is suitable to their family conditions, it raises the social status of the family and it was commercially profitable. The future preferences after completing B.Sc. (Agri.) degree by the respondents were given as, to pursue higher study in India, to prepare for government job and to go abroad for higher studies. More practical based agriculture education shall be provided to the students so that it can arouse interest in agriculture as occupation. Most of the female respondents do not want to join extension jobs, so special counselling shall be conducted to encourage female students towards the extension field.

\section{References}

Chawla, I R., and Shukla A N. 1989. Preferences of undergraduate students for adopting agriculture as a profession and as an occupation. Indian J Ext Edu 25: 30-33.

Frick, M J., Birkenholz, R J, Machtmes, K. 1995. Rural and urban adult knowledge and perceptions of agriculture. J Agric Edu 36: 44-53.

Grewal 2005. Awareness and preferences of rural youth for income generating activities in Ludhiana and Gurdaspur 
districts of Punjab. M.Sc. thesis, Punjab Agricultural University, Ludhiana, India.

Mittal, A. 2005. Preferences and opinion of undergraduate agricultural students towards agriculture as a profession and occupation. M.Sc. thesis. Punjab Agricultural University, Ludhiana, India.

Narwal, R S., and Dixit, V B. 1992. Students Preference Pattern of Agricultural discipline for higher studies. Indian $J$ Ext Edu 28: 133-36.

Punia, R K., and Singh, S. 1981 Job preferences of veterinary undergraduates. Haryana Vet J 20: 6771.

Rashid, M M., Faruque, M G., and Anwar, A B N. 2002. Willingness of dropout unemployed farm youth for undertaking selected entrepreneurships for selfemployment. Bangladesh $J$ Training Dev 15: 53-60.

Sandhu, D K. 1975. A comparative study of aspirations of rural and urban school going girls of Ludhiana District of Punjab. M.Sc. thesis, Punjab Agricultural University, Ludhiana, India.

\section{How to cite this article:}

Boda Mahesh Naik, Rupinder Kaur and Lopamudra Mohapatra. 2019. Preferences of Agricultural Undergraduates of PAU, Ludhiana and PJTSAU, Hyderabad towards Agriculture as a Profession. Int.J.Curr.Microbiol.App.Sci. 8(08): 1787-1796.

doi: https://doi.org/10.20546/ijcmas.2019.808.211 